\title{
Determination of normal values of thymus tissue using neonatal sonography
}

\section{Neonatal sonografi ile normal timus dokusu değerlerinin belirlenmesi}

\author{
Mehmet Burak Ozkan ${ }^{1 *} \mathbb{D}$, Sariye Elif Ozyazici Ozkan ${ }^{2}$ \\ ${ }^{1}$ Antalya Research and Training Hospital, Pediatric Radiology Department, Antalya, Turkey \\ ${ }^{2}$ Antalya Research and Training Hospital, Neonatology Subunit, Antalya, Turkey \\ * Corresponding author: Mehmet Burak Ozkan E-mail: bozkan04@me.com ORCID: 0000-0003-4672-0671 \\ Received: 20 July 2019 Accepted: 2 September 2019
}

\begin{abstract}
Aim: The aim of this study was to determine the normal volumetric values of thymus tissue by sonography in healthy newborns.

Material and Methods: A total of 220 healthy newborns were evaluated by sonography in the first week of life. The shape, size, diameter and thymic index values and variations of both lobes of thymus were evaluated in terms of gestational age, height and weight values and standards were calculated for the reference population.

Results: According to the shape on transverse scans; the thymus was quadrilateral in 136 neonates (61\%), round in 34 (15\%), bilobate in 28 (13\%), and crescent shaped in $22(10 \%)$ in transverse scan. On longitudinal scans, the thymus was triangular in 154 infants (70\%), teardrop shaped in 35 (16\%), oval in 31 (14\%). The range of the thymic transverse diameter along with confidence interval was 1.1-3.9 (mean 2.36 \pm 0.63 ), that of the sagittal area was $1.3-4.93 \mathrm{~cm}^{2}$ (mean $\left.3.01 \pm 0.77\right)$, that of the thymic index was $3.1-16.9 \mathrm{~cm}^{3}$ (mean 9.12 \pm 2.53 ), that of the AP (Right) was $0.40-2.40 \mathrm{~cm}$ (mean $1.37 \pm 0.3$ ), that of the AP (left) was $0.30-3.3 \mathrm{~cm}$ (mean 1.69 \pm 0.48 ) and that of the AP (mean) was 0.35-2.83 (mean \pm 1.27 ).
\end{abstract}

Conclusion: Knowing the reference values in the neonatal period may be meaningful in evaluating the reactive responses of thymus, which is an immunologic organ in this age population.

Keywords: neonatal, thymus, sonography

() 2020 by the authors; licensee MEDITAGEM Ltd., Turkey. This article is an open access article distributed under the terms and conditions of the Creative Commons Attribution License (http://creativecommons.org/licenses/by/4.0/). 


\section{ÖZ}

Amaç: Bu çalışmanın amacı sağlıklı yenidoğanlarda, timus dokusunun normal volumetrik değerlerini sonografi ile tespit etmektir.

Gereç ve yöntemler: Yaşamın ilk haftasında toplam 220 sağlıklı yenidoğan ultrasonografi ile değerlendirildi. Her iki timus lobunun şekil, boyut, çap ve timik indeks değerleri ve varyasyonları gebelik yaşı, boy ve kilo değerleri açısından değerlendirilmiş ve referans popülasyon için standartlar hesaplanmıştır.

Bulgular: Enine taramalardaki şekle göre; timus 136 yenidoğanda [\%61] dörtgen, 34'ünde [\%15] yuvarlak, 28'de [\%13] bilobat ve çapraz taramada 22'de [\%10] hilal şeklindedir. Boyuna taramalarda timüs 154 bebekte [\%70] üçgen şeklinde, gözyaşı şeklinde 35 [\%16], ovalinde 31 [\%14] idi. Timusal transvers çapın güven aralığı ile birlikte aralığı 1,1-3,9 [ortalama $2,36 \pm 0,63$ ], sagital bölgeninki 1,3-4,93 $\mathrm{cm}^{2}$ [ortalama 3,01 $\pm 0,77$ ], timik indeksin 3,1-16,9 cm ${ }^{3}$ [Ortalama 9,12 $\pm 2,53$ ], AP'nin

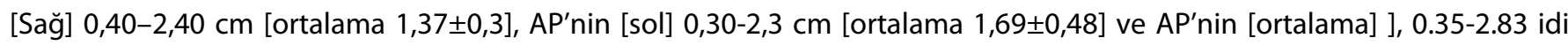
[ortalama $\pm 1,27]$.

Sonuçlar: Yenidoğan döneminde referans değerlerin bilinmesi, bu yaş popülasyonunda immünolojik bir organ olan timusun reaktif tepkilerini değerlendirmede anlamlı olabilir.

Anahtar kelimeler: yenidoğan, timüs, sonografi

\section{INTRODUCTION}

The thymus is a solid organ responsible for the imminological response of lymphoid tissue elements. The thymus is responsible for $T$ cell differentiation and maturation and exhibits volumetric differences in response to stress. The differences between prenatal and postnatal periods were evaluated by sonography method in intrauterine period. The studies evaluating thymus tissue in risky pregnancies in the last trimester are available in the literature [1-6]. Measurement of thymic size in the neonatal period may be useful in assessing the general immunological status of the child and response to sepsis in the neonatal period [7-13].

The aim of this study was to determine thymic index and other volumetric reference values in the newborn population according to changing parametric variances.

\section{MATERIALS AND METHODS}

\section{Patient Selection}

Two hundred twenty healthy newborns were included in the study [gestational week 37 to 42 weeks, mean gestational week 38]. Informed consent was obtained from the parents during the study. The ethic research was obtained by the local committee of the hospital. Gestational age was confirmed by sonographic confirmation by patient age and clinically confirmed according to Ballard criteria. The newborns included in the study were selected from those born by spontaneous vaginal route. Body weight and height were calculated after birth. Apgar scores of the patients were within normal limits. There were no cases of sepsis during the patient follow-up. The patients were followed by the mother after delivery and discharged within 48 hours. The patients were evaluated in terms of prenatal and postnatal factors that would cause volumetric changes in thymus tissue and were selected among the patients who did not develop any problems during follow-up.

\section{Evaluation of Thymus Size}

Thymus sonography was measured with $10-\mathrm{MHz}$ linear probe to prevent variations. Each dimension was repeated 3 times and the mean values were calculated. The focus was placed on both superficial and deep areas, accurate measurement of thymic dimensions, drawing of thymic lines, and good definition of deep extensions.

In all cases, thymus, transternal, parasternal and intercostal approaches were examined in longitudinal and transverse planes. The suprasternal approach was also used to see if there was a suprasternal extension of the thymus. To obtain standardized thymic dimension values, measurements were performed when the thymus had the widest transverse diameter with well-defined contours. The thymic index [TI] was calculated by multiplying the largest transverse diameter by the largest sagittal area and was also analyzed for various clinical variables such as sex, weight, and pregnancy. Changes in the appearance of thymus and echo tissue properties were recorded in both transverse and 
Table 1. Distribution of thymus according to length

\begin{tabular}{|c|c|c|c|c|}
\hline Gestation & $\begin{array}{c}\text { Transverse } \\
\text { diameter range } \\
\text { (mean) } \mathbf{~ c m}\end{array}$ & $\begin{array}{c}\text { AP diameter } \\
\text { range (mean) } \\
\mathbf{~ c m}^{\mathbf{2}}\end{array}$ & $\begin{array}{c}\text { Sagittal area } \\
\text { range (mean) }\end{array}$ & $\begin{array}{c}\text { Thymic index } \\
\text { range (mean) } \\
\mathbf{c m}^{\mathbf{3}}\end{array}$ \\
\hline $\mathbf{3 7}$ & $1.35-3.9$ & $0.4-2.6$ & $1.3-3.9$ & $3.3-13$ \\
\hline $\mathbf{3 8}$ & $1.1-3.7$ & $0.6-2.8$ & $1.42-4.6$ & $3.1-14.2$ \\
\hline $\mathbf{3 9}$ & $1.3-3.5$ & $0.8-2.9$ & $1.7-4.4$ & $3.9-14.6$ \\
\hline $\mathbf{4 0}$ & $1.2-3.8$ & $0.7-3.3$ & $1.6-4.7$ & $4.3-14.3$ \\
\hline $\mathbf{4 1}$ & $1.3-3.3$ & $0.7-3.4$ & $1.8-4.9$ & $4.2-16.9$ \\
\hline
\end{tabular}

Table 2. Distribution of thymus according to sex

\begin{tabular}{|c|c|c|c|c|}
\hline sex & $\begin{array}{c}\text { Transverse } \\
\text { diameter range } \\
\text { (mean) } \mathbf{~ c m ~}\end{array}$ & $\begin{array}{c}\text { AP diameter } \\
\text { range (mean) } \\
\mathbf{c m}^{\mathbf{2}}\end{array}$ & $\begin{array}{c}\text { Sagittal area } \\
\text { range (mean) }\end{array}$ & $\begin{array}{c}\text { Thymic index } \\
\text { range (mean) } \\
\mathbf{c m}^{\mathbf{3}}\end{array}$ \\
\hline male & $1.3-3.9$ & $0.4-3.3$ & $1.3-4.7$ & $3.1-16.2$ \\
\hline female & $1.1-3.8$ & $0.6-3.1$ & $1.4-4.9$ & $3.4-16.9$ \\
\hline
\end{tabular}

Table 3. Distribution of thymus according to weight

\begin{tabular}{|c|c|c|c|c|}
\hline weight & \begin{tabular}{|c|} 
Transverse \\
diameter range \\
(mean) $\mathrm{cm}$
\end{tabular} & $\begin{array}{c}\text { AP diameter } \\
\text { range (mean) } \\
\mathrm{cm}^{2}\end{array}$ & $\begin{array}{l}\text { Sagittal area } \\
\text { range (mean) }\end{array}$ & $\begin{array}{c}\text { Thymic index } \\
\text { range (mean) } \\
\mathrm{cm}^{3}\end{array}$ \\
\hline $2.5-3$ & $1.2-3.9$ & $0.4-2.9$ & $1.3-4.5$ & $3.3-13$ \\
\hline 3-3.5 & $1.1-3.7$ & $0.6-3$ & $1.6-4.7$ & $3.1-16.2$ \\
\hline $3.5-4$ & $1.3-3.8$ & $0.8-3.1$ & $1.8-4.9$ & $3.9-16.9$ \\
\hline
\end{tabular}

longitudinal planes. A single radiologist performed all measurements to eliminate interobserver variations.

\section{STATISTICAL ANALYSIS}

All statistical analyzes were performed with Statplus statistical software.

\section{Thymic Size and Dimensions}

There were 104 male and 116 female neonates, with a median weight of $2.85 \mathrm{Kg}$ [range $2.5-0.4 \mathrm{Kg}$ ] and a median length of $48 \mathrm{~cm}$ [range $41-55 \mathrm{~cm}$ ]. The range of the thymic transverse diameter along with confidence interval was 1.13.9 [mean 2.36 \pm 0.63 ], that of the sagittal area was $1.3-4.93$ $\mathrm{cm} 2$ [mean 3.01 \pm 0.77 ], that of the thymic index was 3.1-16.9 $\mathrm{cm} 3$ [mean 9.12 \pm 2.53 ], that of the AP [Right] was $0.40-2.40$ $\mathrm{cm}$ [mean 1.37 \pm 0.3 ], that of the AP [left] was $0.30-3.3 \mathrm{~cm}$ [mean 1.69 \pm 0.48 ] and that of the AP [mean] was $0.35-2.83$ [mean \pm 1.27 ]. The results are presented in Tables 1-4, which show the distribution of the transverse diameter, the sagittal area, the thymic index and the AP diameter [mean] according to the weight, length, week of gestation and gender by stepwise approach. According to the shape on transverse scans; the thymus was quadrilateral in 136 neonates [61\%], round in 34 [15\%], bilobate in 28 [13\%], and crescent shaped in 22 [10\%] in transverse scan. On longitudinal scans, the thymus was triangular in 154 infants [70\%], teardrop shaped in 35 [16\%], oval in 31 [14\%]. The thymus had left predominance in 55 [25\%], and had right
Table 4. Distribution of thymus according to length

\begin{tabular}{|c|c|c|c|c|}
\hline $\begin{array}{c}\text { length } \\
(\mathbf{c m})\end{array}$ & $\begin{array}{c}\text { Transverse } \\
\text { diameter range } \\
\text { (mean) } \mathbf{~ c m ~}\end{array}$ & $\begin{array}{c}\text { AP diameter } \\
\text { range (mean) } \\
\mathbf{~ c m} \mathbf{2}\end{array}$ & $\begin{array}{c}\text { Sagittal area } \\
\text { range (mean) }\end{array}$ & $\begin{array}{c}\text { Thymic index } \\
\text { range (mean) } \\
\mathbf{~ c m ~} \mathbf{3}\end{array}$ \\
\hline $\mathbf{4 0 - 4 3}$ & $1.35-2.55$ & $0.4-2.9$ & $1.3-3.9$ & $3.1-14.2$ \\
\hline $\mathbf{4 3 - 4 6}$ & $1.1-3.5$ & $0.6-2.8$ & $1.2-4.6$ & $3.4-14.6$ \\
\hline $\mathbf{4 6 - 4 9}$ & $1.2-3.8$ & $0.8-2.9$ & $1.6-4.7$ & $4.4-14.1$ \\
\hline $\mathbf{4 9 - 5 2}$ & $1.4-3.9$ & $0.7-3.3$ & $1.6-4.9$ & $4.3-16.2$ \\
\hline $\mathbf{5 2 - 5 5}$ & $1.3-4.1$ & $0.7-3.4$ & $1.8-4.7$ & $4.2-16.9$ \\
\hline
\end{tabular}

Scatter Diagram (Predicted Y, thymic index vs. length )
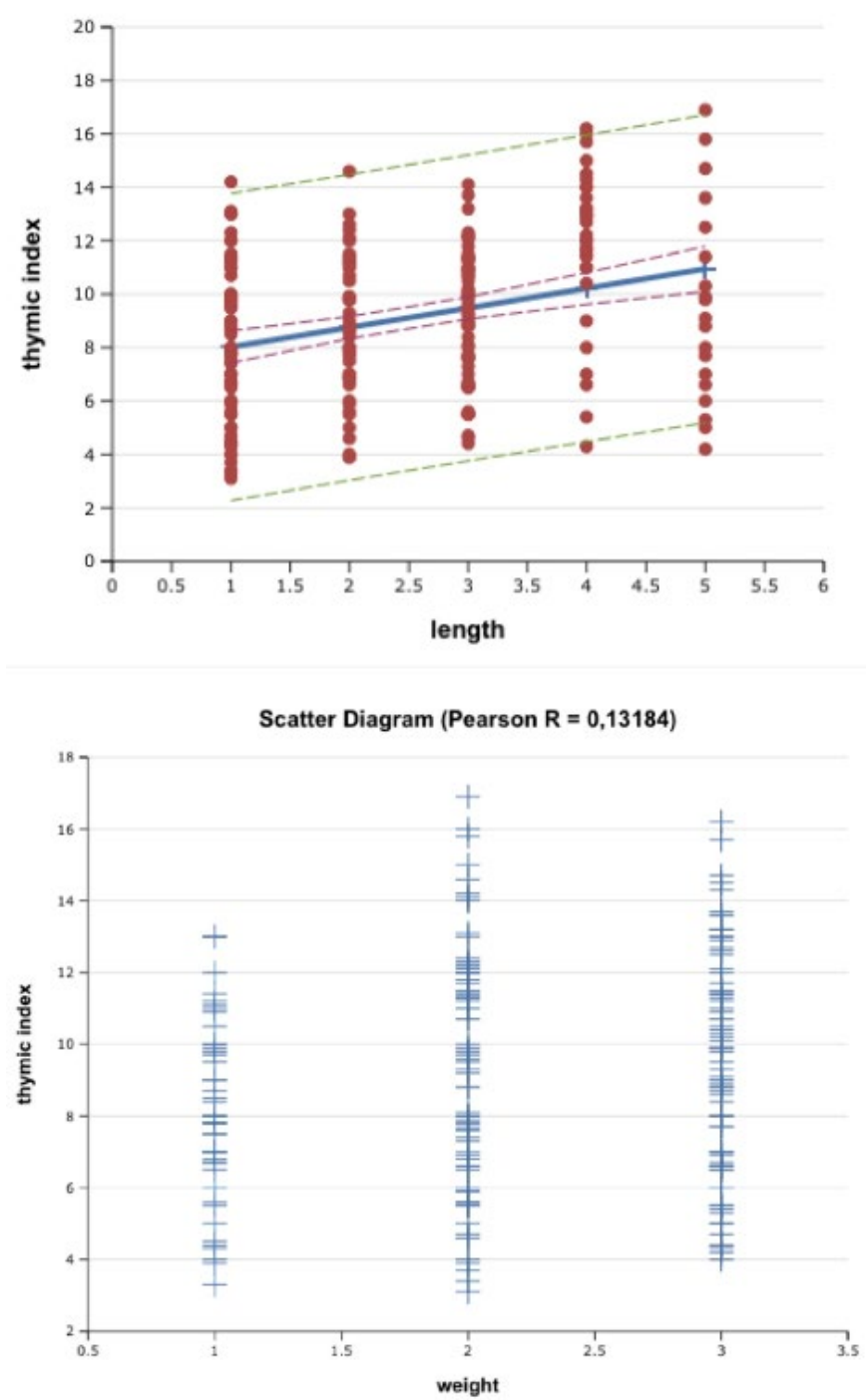

Figure 1. Correlation of thymic index, weight and length

predominance in 28 [13\%]. Results are presented in Tables 1-4.

Figure 1 shows the correlation of thymus size and weight and length.

\section{DISCUSSION}

Thymus is an organ that can be easily evaluated by sonography in neonatal period. Sonography does not contain ionizing radiation especially in childhood, it is easy to reach and can be completed without sedation in a good 
time manner, is an important reason for the preference of chosing $[2,4,5]$. Sonographic evaluation of thymus tissue will be meaningful in terms of reactive responses of newborns followed by sepsis. Although thymus tissue has a specific shape and echogenicity, abnormal variations can be confusing. In order to eliminate these variations and minimize operator-dependent differences, all measurements were made by one person and one machine in our study.

When the measured values in our study were compared with similar studies, differences were found between the dimensions of thymic tissue. It is thought that these basic differences may be due to social developmental differences. In addition, differences in body weight between communities are likely to play a role.

According to some studies, thymus sizes were found to be smaller in girls than boys in the first 2 years [2]. However, there was no difference between the two sexes in proportion to body weight. In our study, thymic volume was found to be higher in girls than in boys. The main reason for this difference is the difference between the population age group between the studies. In addition, the same results were found in our study and the other study in the similar age group.

In our study, a positive correlation was found between thymic index and birth weight and body length. The thymic index obtained as the product of all three dimensions among the thymus size in terms of representation is considered to be the most acceptable parameter for the evaluation of the volume dimension. The correlation between thymic index and body length and correlation with weight were found to be higher. However, these values should be evaluated by studies conducted in large populations.

There are some limitations in our study. Especially for the optimal evaluation of the study, it would be more meaningful to have three inter-correlation coefficients with higher inter-correlation coefficient in the wider population. It would be more meaningful to evaluate sepsis in the preterm population and follow-up of the study. In addition, clinical evaluation of thymus blood flow with doppler sonography will be an additional radiological parameter.

\section{CONCLUSION}

The correlation of thymic index values with height and weight in the newborn period will provide significant results in the evaluation of the cases with variation.

\section{DECLARATION OF CONFLICT OF INTEREST}

The authors received no financial support for the research and/or authorship of this article. There is no conflict of interest.

\section{REFERENCES}

1. Hasselbalch $H$, Jeppesen DL, Ersbøll AK, Lisse IM, Nielsen $M B$. Sonographic measurement of thymic size in healthy neonates: Relation to clinical variables. Acta radiol. 1997.

2. Mehta S. Assessment of thymus size in healthy term neonates using sonography-A study from tertiary care hospital of Central India. J Neonatal Perinatal Med. 2015.

3. Varga I, Nescakova E, Toth F, Uhrinova A, Adamkov M. Nutrition and immune system: the size of the thymus as an indicator of the newborn's nutrition status. Anthropol Anzeiger. 2011.

4. Ekin A, Gezer C, Taner CE, Solmaz U, Gezer NS, Ozeren M. Prognostic value of fetal thy-mus size in intrauterine growth restriction. J Ultrasound Med.

5. Benn CS, Jeppesen DL, Hasselbalch $H$, Olesen AB, Nielsen J, Björkstén $B$, et al. Thymus size and head circumference at birth and the development of allergic diseases. Clin Exp Allergy. 2001.

6. Hanquinet $S$, Rougemont $A L$, Courvoisier $D$, RubbiaBrandt L, McLin V, Tempia M, Anooshiravani M. Acoustic radiation force impulse [ARFI] elas-tography for the noninvasive diagnosis of liver fibrosis in children. Pediatr Radiol [Inter-net]. 2013;43[5]:545-51. Available from: http://ovidsp.ovid.com/ovidweb.cgi?T=JS\&CSC=Y\&NEW $\mathrm{S}=\mathrm{N} \& \mathrm{PAGE}=$ fulltext $\& \mathrm{D}=$ medl $\& A N=23271404 \% 5 \mathrm{Cnhttp}$ : //sfx.bibl.ulaval.ca:9003/sfx_local?sid=OVID:medline\&id =pmid:23271404\&id=doi:10.1007/s00247-012-2595-8\&i ssn $=0301-0449 \& i s b n=\&$ volume $=43 \&$ issue $=5 \&$ spage $=54$ $5 \&$ pages $=545-5$

7. Adam EJ, Ignotus PI. Sonography of the thymus in healthy children: Frequency of visualization, size, and appearance. Am J Roentgenol. 1993.

8. Weissmann-Brenner A, Zemet R, Kivilevitch Z, Zalel Y. Sonographic evaluation of the fetal thymus using the thy-box technique between 13 and 16 weeks' gestation. J Ultrasound Med. 2015.

9. Azad R, Magu S, Gathwala G. Sonographic assessment of the thymus and the measurement of the thymic size in healthy neonates from North India. J Clin Diagnostic Res. 2012. 
10. Lemaitre L, Marconi V, Avni F, Remy J. The sonographic evaluation of normal thymus in infants and children. Eur J Radiol. 1987.

11. Tangshewinsirikul C, Panburana P. Sonographic measurement of fetal thymus size in un-complicated singleton pregnancies. J Clin Ultrasound. 2017.
12. Garly ML, Trautner SL, Marx C, Danebod K, Nielsen J, Ravn $\mathrm{H}$, Martins CL, Balé C, Aaby P, Lisse IM. Thymus Size at 6 Months of Age and Subsequent Child Mortality. Journal of Pediatrics. 2008.

13. Re C, Bertucci E, Weissmann-Brenner A, Achiron R, Mazza $V$, Gindes $L$. Fetal thymus volume estimation by virtual organ computer-aided analysis in normal pregnancies. J Ultrasound Med. 2015. 